\title{
Development of a new cementitious grout for permafrost conditions
}

\author{
S Reny King Packaged Materials Company, Canada \\ J Pena Cruz King Packaged Materials Company, Canada \\ W Clements King Packaged Materials Company, Canada
}

\begin{abstract}
Nowadays underground mining in very cold climates above the 60th parallel is becoming more and more common. Furthermore, automatisation of the ground control process is also now a key in mining efficiencies. This new era brings new technical challenges for methods and products to perform under such cold temperatures. The grouted portion of the cable bolt system is critical to the success of the cable installation and ensure proper ground support. Normal Portland based cement will not properly hydrate in temperatures below the freezing point. King Packaged Materials Company (King) has developed a grout technology that has been adapted for several permafrost grouting applications including grout for pile construction of surface infrastructure, fluid consistency neat grout for cable bolting using the breather tube method and a thick consistency neat grout for an automatic cable bolter using the grout and insert method. This paper describes the mixing, placing and curing conditions under which this cementitious grout must be placed in the various applications used so far. Secondly it covers the test programs conducted under laboratory conditions to demonstrate performance of the new developed cementitious grout under such cold conditions. The third portion of this paper provides information on the in situ test programs used for each application. Finally, it reviews the different test results obtained under the different testing conditions.
\end{abstract}

The intent of this paper is to demonstrate that installation of cement grouted cable can be achieved using several different applications methods under permafrost conditions.

Keywords: permafrost, grout, cable bolting, cable bolter, freezing, ground control, automatisation

\section{Introduction}

Cementitious grouts for various ground support applications have been utilised by the mining industry for decades. As the limits of mining geography are expanding, new challenges are encountered. In the Great Canadian North, extremely low temperatures restrain the use of normal cementitious grout. Parallel to these new extreme conditions, the mining industry is also facing a new era wherein new equipment technology is being used to accelerate the mining process and reduce the risk of injury by reducing manual operations. Automatic cable bolters are the perfect example of this new type of equipment technology (Marek et al. 2012). This new type of equipment can be designed with an automatic batching and injection system for cementitious grout, but the current bolters were designed for normal cementitious grout which would not perform in freezing conditions. Combining low temperature applications with the automatic bolting system, required that the normal cementitious grout undergo re-engineering. Based on a known existing cementitious technology for filling structural piles in permafrost, the research and development team determined that the industry would need adapted versions of this grout. The grout would need to be either installed automatically or manually at a fluid consistency for breather tube method or at a thicker consistency for grout and insert method. These new concepts increase the level of complexity of the grout formulation as it had to be sufficiently fluid for a certain period of time to allow placement, but must set quickly to generate enough heat in order to avoid freezing which would permanently damage the grout. To begin this article covers the test program conducted under laboratory conditions created to replicate the field condition of the new developed grout in order to demonstrate the potential in situ. The second portion of the article 
describes the parameters required for mixing, placing and curing the grout depending on the various applications encounter in that region. Thirdly the article provides results obtained from the in situ testing campaign for thicker grout developed to be used with a cable bolter. The last section summarises and analysis the obtained test results from the various phases of the test program. The reader will be able to understand the complexity of such a research and development program, and will also be able to appreciate new potential fields of application for cementitious grouting methods used in underground support.

\section{$2 \quad$ Laboratory development methodology}

Although the first cementitious grouts for permafrost applications were originally developed for structural piles used in foundations for infrastructure in Northern climates, it was possible to adapt the technology to the cable bolting practices currently used in Canadian mines. The initial adaptation was to remove the fine aggregate from the mix design and to develop a neat (unsanded) version of the permafrost grout. This was required as mines possess all different kinds of pumping equipment, and considering that sanded grout does not pump well when used with a rotor-stator (pigtail or screw) style pump it was determined to create a neat grout that could be pumped using a rotor-stator pump or piston pump. The other consideration during the design of the neat permafrost grout was the ambient temperature in the mine which ranged from $5^{\circ} \mathrm{C}$ to $-20^{\circ} \mathrm{C}$, and the generally smaller volume of the grouted boreholes compared to that of the structural piles. Normally the permafrost grout for structural piles is batched in a temperature controlled environment (Figure 1) conditioned to $21-25^{\circ} \mathrm{C}$, and the pre-packaged grout and mixing water are also pre-conditioned in order to produce grout at a plastic temperature ranging from $21-25^{\circ} \mathrm{C}$.

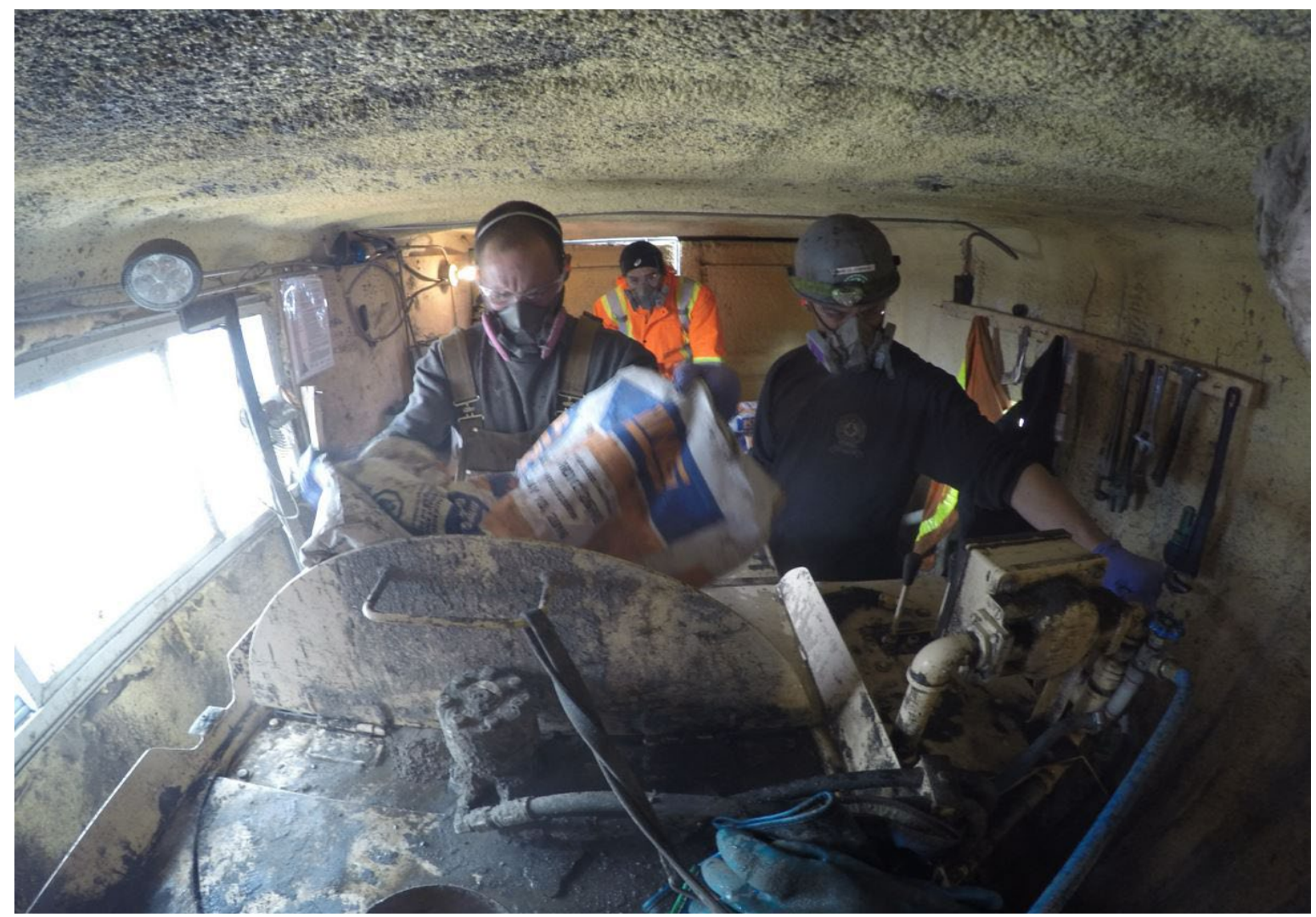

Figure 1 Grout batch plant stored in insulated and heated container

Considering the ambient temperature of the mine and the fact that it was not practical for the mine to heat the new neat permafrost grout, the grout was developed in the laboratory by preconditioning all of the dry-blended grout to $-20^{\circ} \mathrm{C}$ and the water to $5-10^{\circ} \mathrm{C}$ in order to achieve a plastic grout temperature of $5-8^{\circ} \mathrm{C}$. The typical structural pile poured with permafrost grout has a diameter of 100 to $200 \mathrm{~mm}$ and is free from reinforcing steel, whereas boreholes used for cable bolting range from 50 to $75 \mathrm{~mm}$ and include a steel cable 
that acts a conduit for cooling the grout during application and hydration. In order to predict success in the field during the development phase the testing protocol had to model the in situ application as closely as possible. During the development of the permafrost grout for structural piles, $100 \mathrm{~mm}$ (diameter) $\times 200 \mathrm{~mm}$ (height) cylinders were used for compressive strength (ASTM C39) (ASTM International 2018) determination wherein the cast grout cylinders were placed into a controlled environment at a temperature of $-10^{\circ} \mathrm{C}$ until testing was completed at the desired age. The neat permafrost grout was subsequently developed using $75 \mathrm{~mm}$ (diameter) $\times 150 \mathrm{~mm}$ (height) cylinders in order to best model the size of the borehole in the mine, and the heat development that occurred in the material during hydration. Heat development monitoring under permafrost temperature conditions is a good indicator of future mechanical performance of cementitious product, as demonstrated in the development of a shotcrete for permafrost ground applications (Dufour \& Beaupré 1999). Since the reinforcing cable used inside of the borehole can act as a conduit to encourage heat transfer from the grout to the steel and rock as it is hydrating, a series of tests were conducted using $75 \mathrm{~mm}$ (diameter) $\times 150 \mathrm{~mm}$ (height) cylinders containing a $15 \mathrm{M}(15 \mathrm{~mm})$ reinforcing bar cast into the grout in order to observe the heat development of the grout (Figure 2). A thermocouple wire was connected both to the $15 \mathrm{M}(15 \mathrm{~mm})$ reinforcing bar and the outside of the cylinder in order to determine the maximum temperature that was achieved by the grout during hydration.

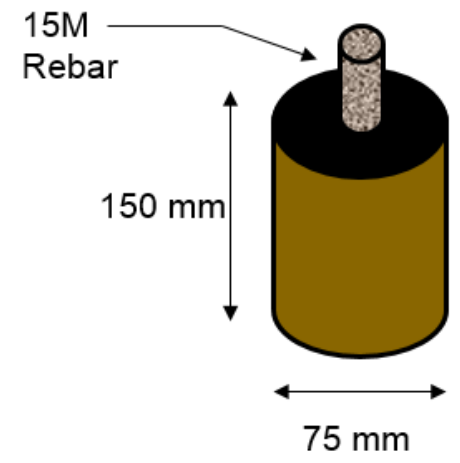

Neat Permafrost Grout

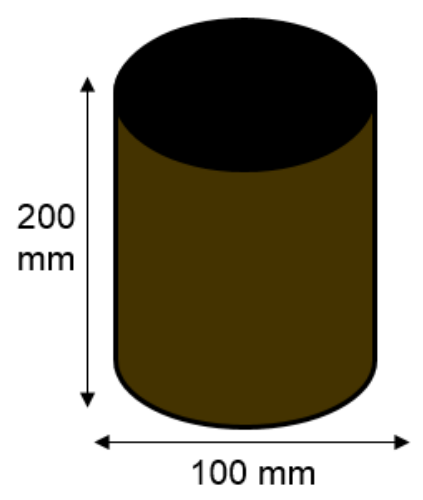

Pile Permafrost Grout

Figure 2 Schematic comparing the sample size of the pile permafrost grout to the neat permafrost grout

\section{$3 \quad$ In situ testing}

\subsection{Background}

A neat permafrost grout possessing a thick consistency was tested in the field. For the remainder of the document, the neat permafrost grout possessing a thick consistency will be referred to as the TC permafrost grout for the sole purpose of lightening the text. The TC permafrost grout was developed to be used in the field with a cable bolter, and the plasticity of the grout had to be adapted in order to be used with this new type of equipment. When a cable bolter is used to install cable bolts underground, a grout tube is first inserted all the way to the toe of the borehole. As the borehole is grouted, the grout tube is progressively retracted until it reaches the collar of the borehole. This method is consistent with the 'grout and insert' method (Hutchinson \& Diederichs 1996) as the borehole is grouted prior to the insertion of the cable bolt. Once the borehole is grouted, the cable bolt is installed by the cable bolter. Unlike other installation methods such as the 'breather tube' method (Hutchinson \& Diederichs 1996), the collar is not sealed and therefore the plasticity and cohesiveness of the grout are critical to ensure that the grout stays in place during pumping, after pumping and when the cable bolt is inserted. A visual example of the plasticity and cohesiveness of the TC permafrost grout is shown in Figure 3. Furthermore, both grouting methods mentioned herein are depicted in Figure 4. 


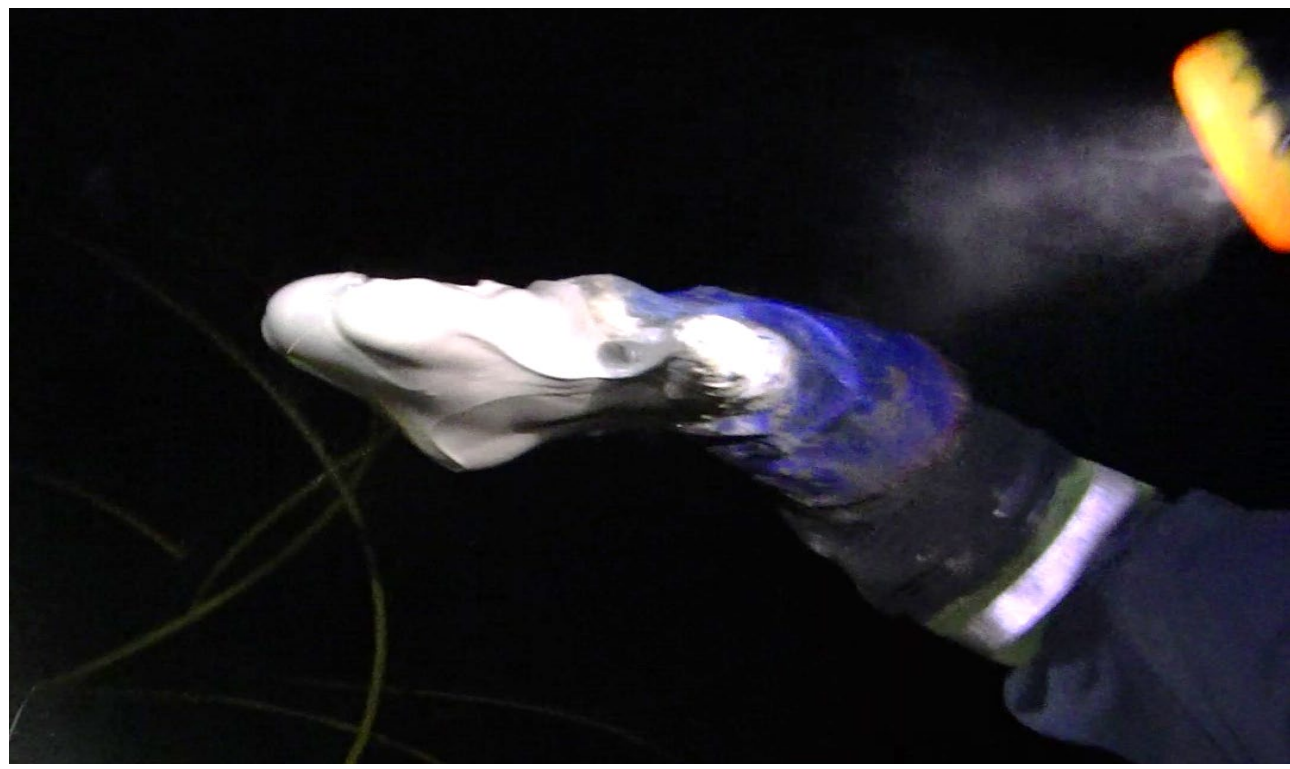

Figure 3 Schematic of plasticity and cohesiveness of thick consistency permafrost grout required for 'grout and insert' method as per Hutchinson \& Diederichs (1996)
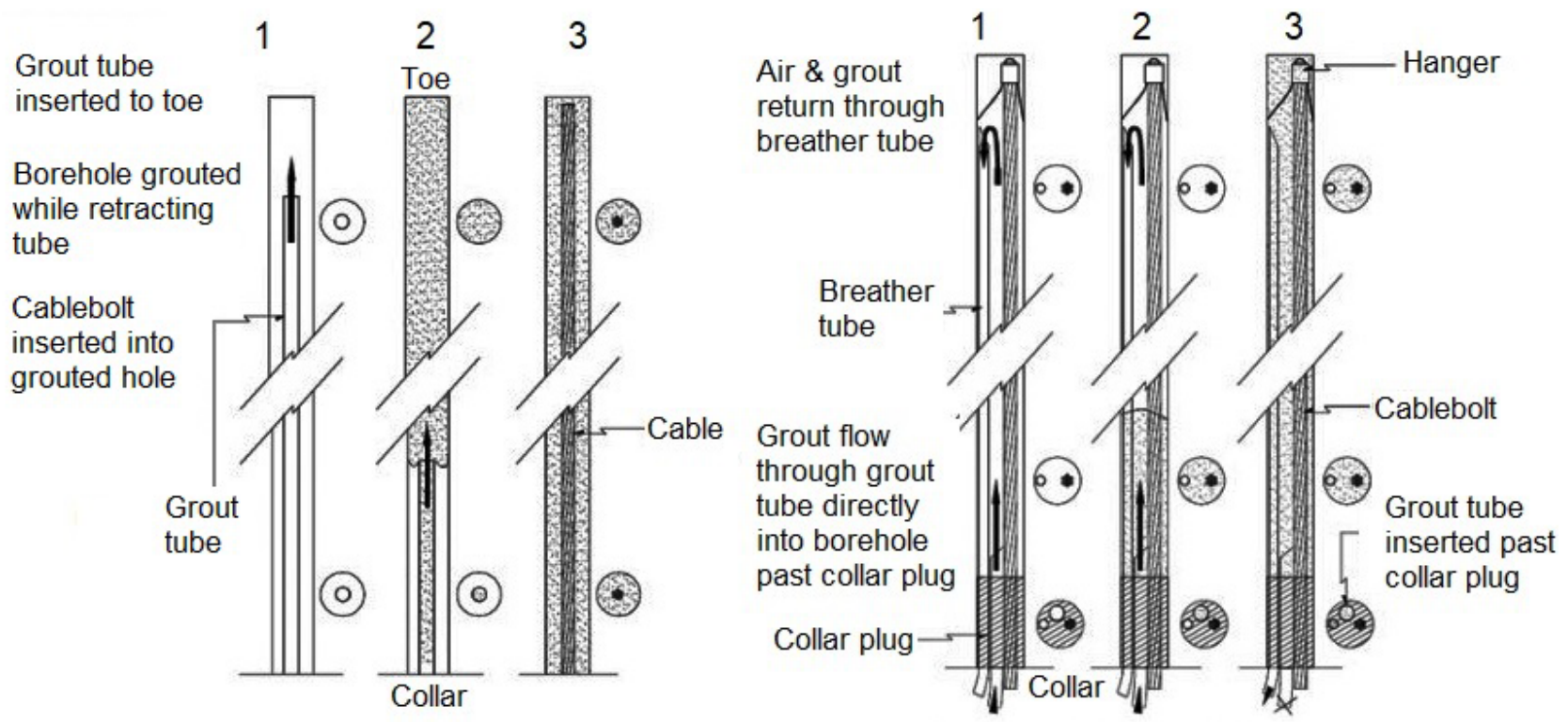

Figure 4 'Grout and insert' (left) and 'breather tube' (right) grouting methods (Hutchinson \& Diederichs 1996)

In situ trials were organised using the TC permafrost grout in an underground mining environment to verify the results obtained in the laboratory. Furthermore, trials conducted in the field are key to take into account actual ambient conditions, effects of the in situ water source on grout performance and to evaluate the functionality and efficiency of the grout batch plant used to fabricate and pump the grout in the field. It is important to note that the trials were conducted during August 2018, which would be considered a warmer period of the year at the mine site.

\subsection{Batching and pumping equipment}

The grout plant used for the trials was provided by the mine site and presented different parameters than the grout plant mounted on a cable bolter. It is important to note that the trials had to be conducted prior to the arrival of the cable bolter at the mine location. The grout plant used for the trials possessed a $170 \mathrm{~L}$ 
mixing tank with an integrated paddle mixer. The plant was also equipped with an intermediate holding hopper over the rotor-stator pump.

Due to the equipment limitation, the grouting method implemented for the trials was the 'grout tube' method (Hutchinson \& Diederichs 1996) which is the most similar grouting method in terms of the required grout plasticity in the 'grout and insert' method (Hutchinson \& Diederichs 1996), as shown in Figure 4. The grouting method used for the trials is depicted in Figure 5.

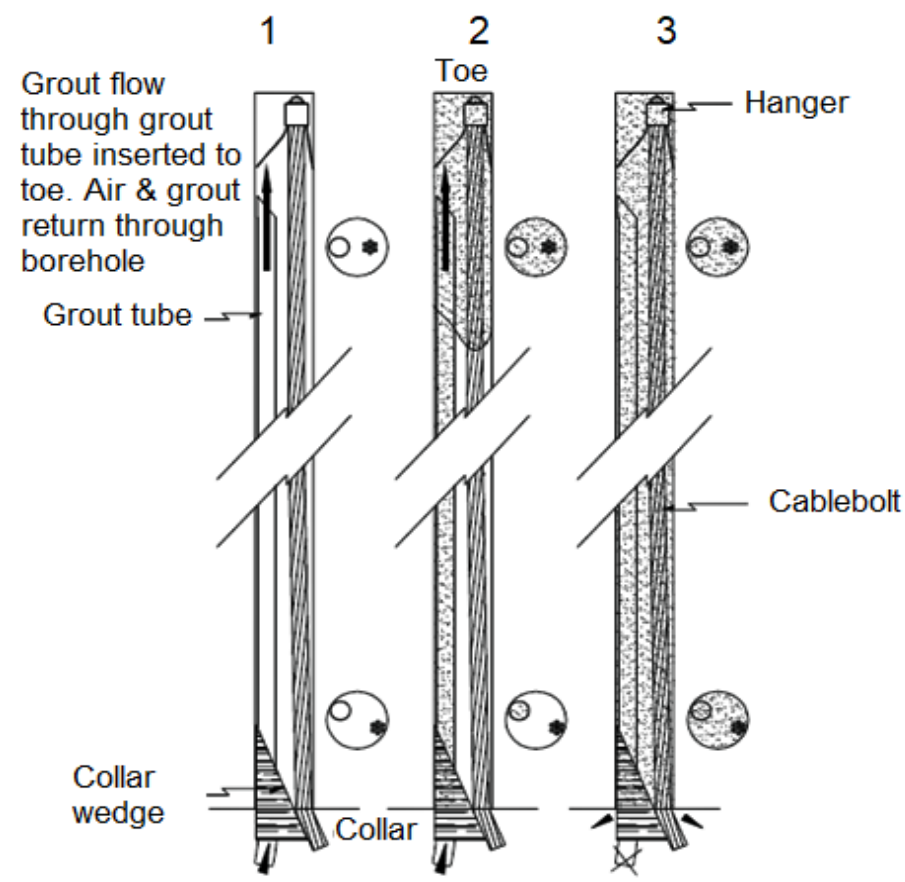

Figure 5 'Grout tube' grouting method (Hutchinson \& Diederichs 1996)

\subsection{Instrumentation for temperature monitoring}

During the cable bolt installation, thermocouple wires were attached to the cable bolts prior to inserting them in the boreholes to measure and record the temperature inside the borehole prior to grouting and to monitor the temperature development of the grout during the hardening phase. Dataloggers (Figure 6) were also left in the drift to record local ambient temperature.

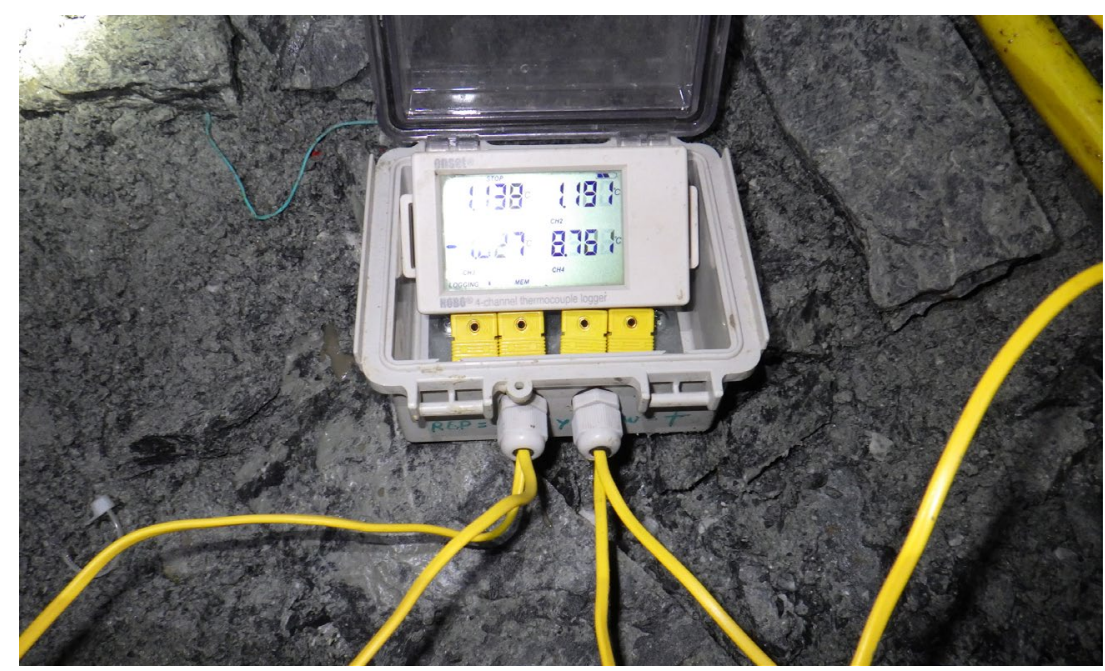

Figure 6 Datalogger used to monitor temperature 


\subsection{Batching and pumping procedure}

Cable bolts were grouted in two different levels of the underground mine which are referred to as level 200 (upper) and level 400 (lower) in the present document. At each level, two batches were prepared: the first was to be prepared with freshwater recovered at the surface of the mine and the second mine, with brine water which is readily accessible underground. Grout batch parameters are presented in Table 1.

Table $1 \quad$ Overview of grout batch parameters

\begin{tabular}{lcccc}
\hline Batch description & $\begin{array}{c}\text { Total water } \\
\text { (litres) }\end{array}$ & $\begin{array}{c}\text { Pre-packaged grout } \\
\text { material (kg) }\end{array}$ & $\begin{array}{c}\text { Water-material } \\
\text { ratio }\end{array}$ & $\begin{array}{c}\text { Grout plastic } \\
\text { temperature }\left({ }^{\circ} \mathrm{C}\right)\end{array}$ \\
\hline Level 200 - freshwater & 63 & 225 & 0.28 & 11.4 \\
Level 200 - brine water & 63 & 225 & 0.28 & 12.9 \\
Level 400 - freshwater & 68 & 225 & 0.30 & 12.4 \\
Level 400 - brine water & 68 & 225 & 0.30 & 13.9 \\
\hline
\end{tabular}

Before commencing the batching process, the quantity of water was measured prior to adding the dry product inside the mixing tank. The grout plant was not equipped with a water meter and a plastic pail was calibrated in order to measure the water volume used per batch. Approximately $75 \%$ of the total batching water was firstly added into the mixing tank. The dry product was then gradually added into the mixing tank. The remaining $25 \%$ of the batching water was added during this step to help with the mixing of the product. When the grout appeared to be homogeneous, it was discharged into the lower hopper and recirculated back into the mixing tank. Once the grout appeared to have the adequate thick consistency, the grouting operation began.

The grout was pumped through the flexible main hose. The plastic grout tube was inserted into the flexible main hose. A modified vice-grip wrench with two welded ' $C$ ' shaped holders was used to tightly clamp the main hose over the grouting tube while pumping. The grout is pumped into the borehole from the toe to the collar. When the grout slowly exited the collar, the pumping was stopped and the next grout tube was connected to proceed with the pumping operation. A grouted cable bolt is shown in Figure 7.

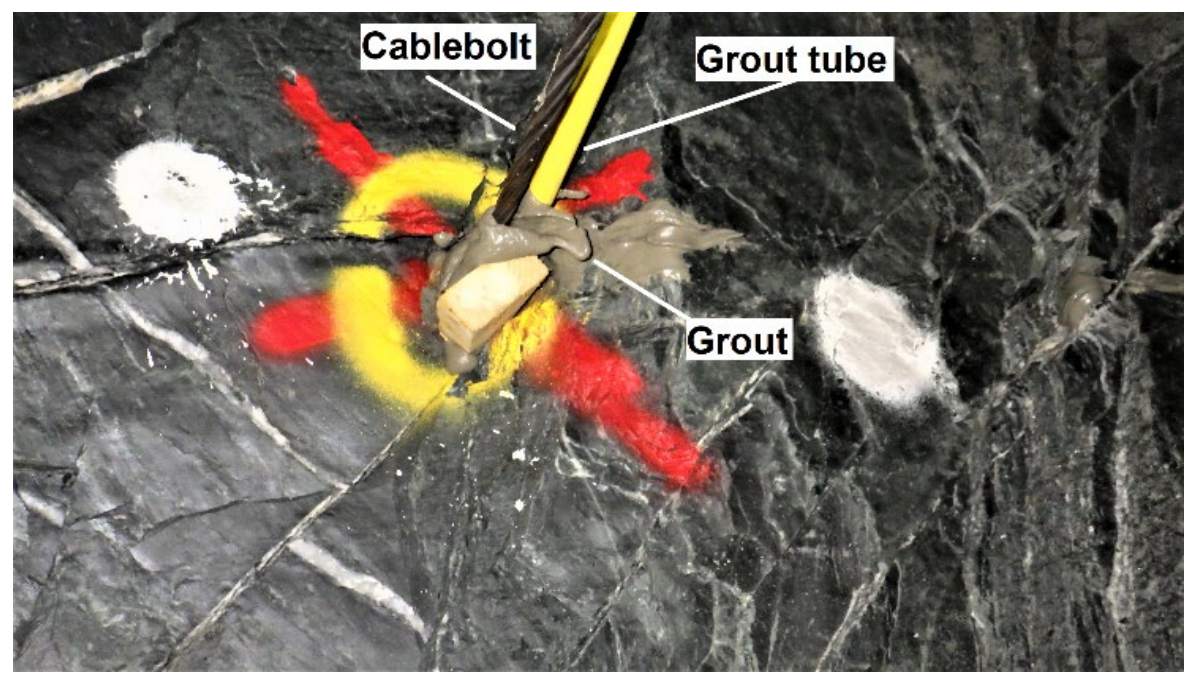

Figure 7 Grouted cable using the 'grout tube' method (Hutchinson \& Diederichs 1996)

\subsection{Compressive strength specimen preparation}

Thirty-six (36) $100 \mathrm{~mm}$ (diameter) by $200 \mathrm{~mm}$ (height) cylinders were prepared underground. These cylinders were later used to determine the compressive strength of the hardened grout in accordance with ASTM C39 (ASTM International 2018). All cylinders were left in the drift until the test date. 


\section{$4 \quad$ Results and discussion}

\subsection{Laboratory grout compressive strength}

Several iterations of the neat permafrost grout and TC permafrost grout were tested and evaluated based on plastic properties, compressive strength and heat development. The data presented in Table 2 is indicative of the final formulation of the respective permafrost grouts. The grout was batched at a plastic temperature of $5-10^{\circ} \mathrm{C}$ and all of the data was obtained using $100 \mathrm{~mm}$ (diameter) by $200 \mathrm{~mm}$ (height) cylinders prepared in laboratory conditions $\left(21-25^{\circ} \mathrm{C}\right.$ ) and cured in a temperature controlled environment at $-10^{\circ} \mathrm{C}$ immediately after casting until the indicated testing age.

Table 2 Laboratory grout compressive strength results

\begin{tabular}{lccc}
\hline Consistency & $\begin{array}{c}\text { Age of break } \\
\text { (days) }\end{array}$ & $\begin{array}{c}\text { Compressive } \\
\text { strength (MPa) }\end{array}$ & $\begin{array}{c}\text { Compressive strength } \\
\text { average (MPa) }\end{array}$ \\
\hline & 1 & 50.7 & 46.4 \\
Fluid & 7 & 42.0 & 49.1 \\
(neat permafrost grout) & 7 & 50.8 & \\
& 28 & 47.3 & 49.5 \\
& 28 & 51 & 36.5 \\
Thick consistency & 1 & 48 & 39.6 \\
(TC permafrost grout) & 1 & 36.8 & \\
& 7 & 36.1 & 41.3 \\
& 28 & 38.7 & \\
\hline
\end{tabular}

The compressive strength of both the fluid permafrost grout and TC permafrost grout met the typical requirement of $20 \mathrm{MPa}$ at 24 hours which is used by most mines as a benchmark for cable bolting. The compressive strength of the fluid permafrost grout was found to be slightly higher than the compressive strength of the TC permafrost grout, which could be due to the fact that the TC permafrost grout is slightly more difficult to cast due to the higher viscosity of the grout. It should also be noted that an increase in compressive strength between days 1, 7 and 28 is not significant, although is typical for the permafrost grout technology considering most of the compressive strength is developed within the first 24 hours.

\subsection{Laboratory temperature monitoring}

Several iterations of the neat permafrost grout and TC permafrost grout were evaluated for heat development using a 15M reinforcing bar placed into a $100 \mathrm{~mm}$ (diameter) by $200 \mathrm{~mm}$ (height) cylinder. The graph presented in Figure 8 represents the heat development of the final formulation of the TC permafrost grout. All of the data was obtained using thermocouple wire inside of both a normal $100 \mathrm{~mm}$ (diameter) by $200 \mathrm{~mm}$ (height) cylinder, and inside of a $100 \mathrm{~mm}$ (diameter) by $200 \mathrm{~mm}$ (height) cylinder containing a 15M reinforcing bar. The grout was batched at a plastic temperature of $5-10^{\circ} \mathrm{C}$, all of the cylinders were prepared in laboratory conditions $\left(21-25^{\circ} \mathrm{C}\right)$ and cured in a temperature controlled environment at $-10^{\circ} \mathrm{C}$ immediately after casting. 


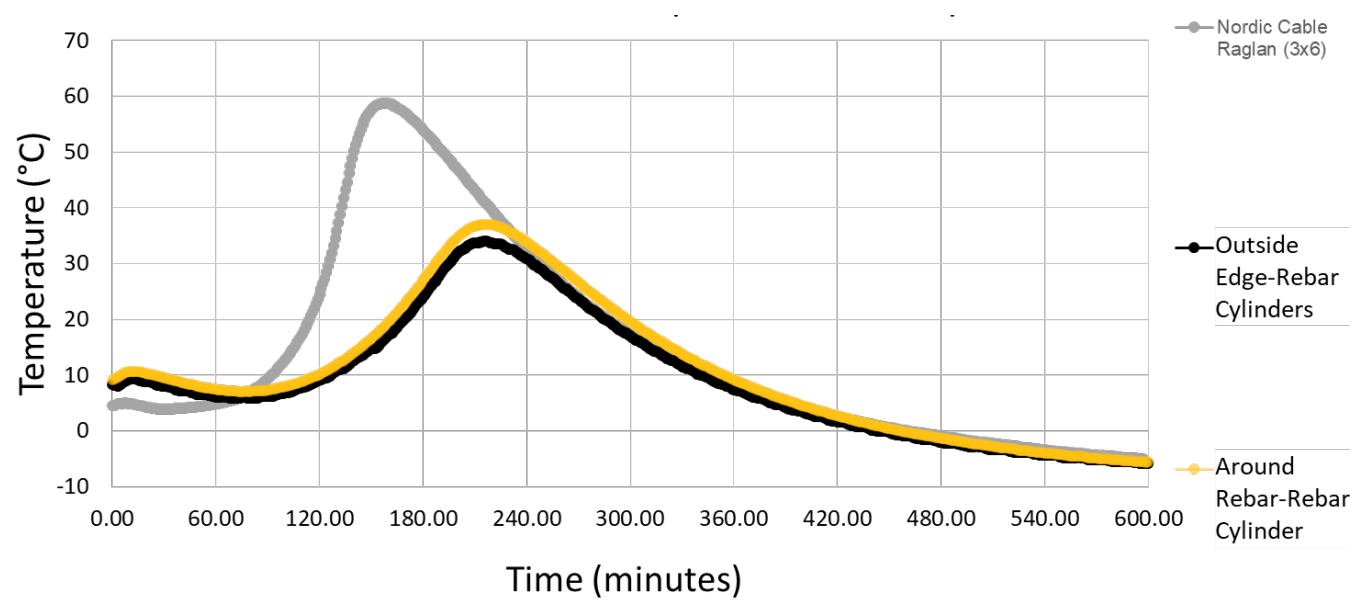

Figure 8 Thick consistency permafrost grout heat development

The heat developed by the TC permafrost grout begins to peak starting at around 90 minutes after batching in a normal $100 \mathrm{~mm}$ (diameter) by $200 \mathrm{~mm}$ (height) cylinder, and around 120 minutes after batching in a $100 \mathrm{~mm}$ (diameter) by $200 \mathrm{~mm}$ (height) cylinder containing a $15 \mathrm{M}$ rebar. Consequently, a maximum temperature of $60^{\circ} \mathrm{C}$ was achieved in a normal $100 \mathrm{~mm}$ (diameter) by $200 \mathrm{~mm}$ (height) cylinder, and a maximum temperature of $38^{\circ} \mathrm{C}$ was achieved in a normal $100 \mathrm{~mm}$ (diameter) by $200 \mathrm{~mm}$ (height) cylinder containing a $15 \mathrm{M}$ rebar. Based on this data it is clear to see that the inclusion of a $15 \mathrm{M}$ rebar makes the design more conservative, as the $15 \mathrm{M}$ rebar serves as a conduit to cool the grout as it hydrates while also slightly reducing the volume of grout available in the cylinder.

\subsection{In situ grout compressive strength}

Thirty-six (36) $100 \mathrm{~mm}$ (diameter) by $200 \mathrm{~mm}$ (height) cylinders were prepared underground. Eighteen (18) cylinders were prepared at level 200 (upper) and 18 cylinders at level 400 (lower). Hardened grout cylinders were brought to surface on the test date and tested in a compressive strength machine supplied by the mine site. Compressive strength results of the hardened grout are individually presented in Tables 3 and 4 , for level 200 (upper) and level 400 (lower), respectively.

Table 3 Grout compressive strength results for level 200 (upper) - 8 August 2018 (continued next page)

\begin{tabular}{|c|c|c|c|c|}
\hline $\begin{array}{l}\text { Specimen } \\
\text { description }\end{array}$ & Casting date & $\begin{array}{l}\text { Age of break } \\
\text { (days) }\end{array}$ & $\begin{array}{l}\text { Compressive } \\
\text { strength } \\
\text { (MPa) }\end{array}$ & $\begin{array}{c}\text { Compressive } \\
\text { strength } \\
\text { average (MPa) }\end{array}$ \\
\hline 200-01-FR & 10 August 2018 & 2 & 32.4 & \\
\hline 200-02-FR & 10 August 2018 & 2 & 34.9 & 33.5 \\
\hline 200-02-FR & 10 August 2018 & 2 & 33.3 & \\
\hline 200-04-FR & 11 August 2018 & 3 & 24.5 & \\
\hline 200-05-FR & 11 August 2018 & 3 & 33.6 & 29.2 \\
\hline 200-06-FR & 11 August 2018 & 3 & 29.5 & \\
\hline 200-07-FR & 13 August 2018 & 5 & 27.4 & \\
\hline 200-08-FR & 13 August 2018 & 5 & 28.1 & 29.4 \\
\hline 200-09-FR & 13 August 2018 & 5 & 32.8 & \\
\hline 200-10-BR & 10 August 2018 & 2 & 23.4 & 23.0 \\
\hline
\end{tabular}




\begin{tabular}{lllll} 
200-11-BR & 10 August 2018 & 2 & 24.1 & \\
200-12-BR & 10 August 2018 & 2 & 21.4 & \\
\hline $200-13-B R$ & 11 August 2018 & 3 & 23.7 & 25.3 \\
$200-14-B R$ & 11 August 2018 & 3 & 25.5 & \\
$200-15-B R$ & 11 August 2018 & 3 & 26.7 & \\
\hline $200-16-B R$ & 13 August 2018 & 5 & 26.9 & 25.4 \\
$200-17-B R$ & 13 August 2018 & 5 & 25.8 & \\
$200-18-B R$ & 13 August 2018 & 5 & 23.5 & \\
\hline
\end{tabular}

XXX-XX - [Level]-[specimen identification]; FR - Freshwater batch; BR - Brine water batch.

Table 4 Grout compressive strength results for level 400 (upper) - 8 August 2018

\begin{tabular}{|c|c|c|c|c|}
\hline $\begin{array}{l}\text { Specimen } \\
\text { description }\end{array}$ & Casting date & $\begin{array}{l}\text { Age of break } \\
\text { (days) }\end{array}$ & $\begin{array}{l}\text { Compressive } \\
\text { strength } \\
\text { (MPa) }\end{array}$ & $\begin{array}{c}\text { Compressive } \\
\text { strength } \\
\text { average ( } \mathrm{MPa})\end{array}$ \\
\hline 400-01-FR & 10 August 2018 & 2 & 21.3 & \\
\hline $400-02-F R$ & 10 August 2018 & 2 & 27.9 & 24.6 \\
\hline 400-03-FR & 10 August 2018 & 2 & 24.5 & \\
\hline 400-04-FR & 11 August 2018 & 3 & 30.2 & \\
\hline 400-05-FR & 11 August 2018 & 3 & 24.1 & 26.0 \\
\hline 400-06-FR & 11 August 2018 & 3 & 23.7 & \\
\hline 400-07-FR & 13 August 2018 & 5 & 35.7 & \\
\hline $400-08-F R$ & 13 August 2018 & 5 & 37.4 & 34.9 \\
\hline 400-09-FR & 13 August 2018 & 5 & 31.7 & \\
\hline $400-10-B R$ & 10 August 2018 & 2 & 22.1 & \\
\hline $400-11-B R$ & 10 August 2018 & 2 & 24.4 & 23.6 \\
\hline $400-12-B R$ & 10 August 2018 & 2 & 24.4 & \\
\hline $400-13-B R$ & 11 August 2018 & 3 & 21.8 & \\
\hline 400-14-BR & 11 August 2018 & 3 & 23.4 & 22.8 \\
\hline $400-15-B R$ & 11 August 2018 & 3 & 23.1 & \\
\hline $400-16-B R$ & 13 August 2018 & 5 & 22.1 & \\
\hline 400-17-BR & 13 August 2018 & 5 & 20.5 & 21.7 \\
\hline 400-18-BR & 13 August 2018 & 5 & 22.6 & \\
\hline
\end{tabular}

XXX-XX - [Level]-[specimen identification]; FR - Freshwater batch; BR - Brine water batch.

In general, compressive strength of the TC permafrost grout was higher when batched with freshwater. On level 200 after five days of curing, the freshwater set of cylinders averages $29.4 \mathrm{MPa}$ while the brine water set of cylinders averages $25.4 \mathrm{MPa}$. On level 400 after five days of curing, the freshwater set of cylinders averages $34.9 \mathrm{MPa}$ while the brine water set of cylinders averages $21.7 \mathrm{MPa}$. 


\subsection{Temperature monitoring}

\subsubsection{In situ ambient and empty borehole}

The ambient temperature of each trial location-level 200 (upper) and level 400 (lower)-was monitored by means of a HOBO 4-Channel Thermocouple Data Logger - UX120-014M. The datalogger itself was left in the drift to record the ambient temperature whereas the thermocouples were used to monitor the temperature inside the boreholes before and after grout placement. Thermocouples installed in the boreholes monitored grout temperature development as well, as they were left inside the boreholes for over 24 hours. Results are shown on Table 5 and complementary results from April 2018 have been added for comparison.

Table 5 Ambient and empty borehole temperature

\begin{tabular}{lcc}
\hline Level - date & $\begin{array}{c}\text { Average } \\
\text { ambient }\left({ }^{\circ} \mathrm{C}\right)\end{array}$ & $\begin{array}{c}\text { Average in empty } \\
\text { boreholes }\left({ }^{\circ} \mathrm{C}\right)\end{array}$ \\
\hline Level 200 (upper) - August 2018 & 8.92 & 5.55 \\
Level 400 (lower) - August 2018 & 10.17 & 6.78 \\
Level 200 (upper) - April 2018 & -0.49 & -0.40 \\
\hline
\end{tabular}

Results show a spike of temperature from April to August in the same year (2018) which also seem to have an influence on the temperature of the rock mass as the temperature recorded inside the boreholes is also higher than the results obtained in April 2018.

At level 200 (upper), the average ambient temperature was calculated to be $8.92^{\circ} \mathrm{C}$ from 7-13 August 2018 . When considering all data collected from the four thermocouples installed inside the boreholes at level 200 (upper) on 7 August 2018, the average temperature was calculated to be $5.55^{\circ} \mathrm{C}$.

Following temperature observations on level 200 (upper), it was decided that one thermocouple at level 400 (lower) would be used to measure the temperature development inside a grout cylinder which would be exposed to a much higher temperature than the grout inside the boreholes.

At level 400 (lower), the average ambient temperature was calculated to be $10.17^{\circ} \mathrm{C}$ from $7-13$ August 2018. When considering all data collected from the three thermocouples installed inside the boreholes at level 400 (lower) on 8 August 2017, the average temperature was calculated to be $6.78^{\circ} \mathrm{C}$.

\subsubsection{Grout}

The grout temperature development on level 200 (upper) and level 400 (lower) was monitored by a total of four thermocouples attached to the grouting tube approximately $300 \mathrm{~mm}$ from the toe of the borehole. All results obtained with TC permafrost grout batched with freshwater are illustrated in Figure 9 and results with TC permafrost grout batched with brine water are illustrated in Figure 10.

On each graphic, the 'first-peak' of temperature represents the first contact between the freshly batched grout and the thermocouple wire. At that precise moment, it is considered that the grouting of the cable bolt has begun. The temperature gradually goes down as the rock mass temperature, the temperature of the steel cable bolt and the temperature of the plastic grout tube are lower than the grout temperature.

As the hydration process begins in the TC permafrost grout, the temperature rises and reaches its second peak (hydration peak) and begins to achieve early age compressive strength. After the second-peak, the temperature begins to drop and will tend to reach the temperature of the rock mass $\left(5.55^{\circ} \mathrm{C}\right.$ average in level 200 and $6.78^{\circ} \mathrm{C}$ average in level 400 ).

Table 6 summarises different hydration peaks captured by the datalogger. Peaks appear to be higher than those measured during the April 2018 trial which is normal as the ambient temperature $\left(-0.49^{\circ} \mathrm{C}\right.$ average) and rock mass temperature $\left(-0.40^{\circ} \mathrm{C}\right.$ average) were significantly lower in April 2018. 


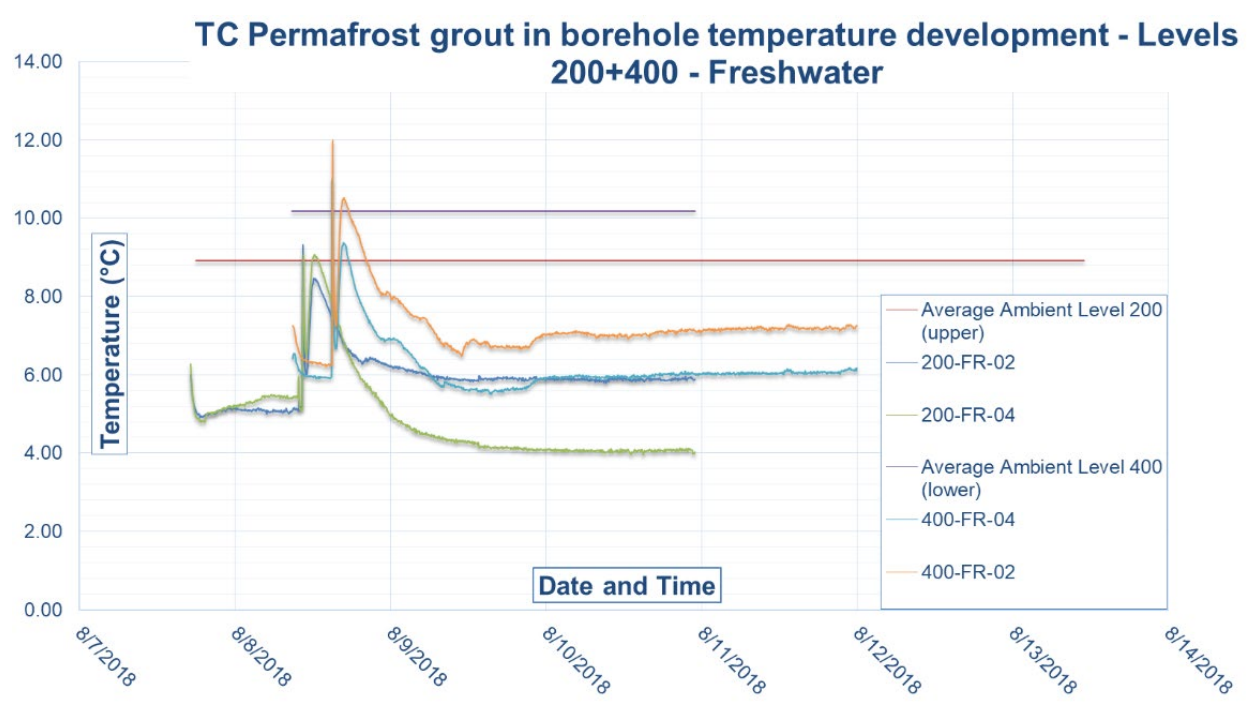

Figure 9 Thick consistency permafrost grout temperature development - level 200 (upper) \& and level 400 (lower); freshwater batches

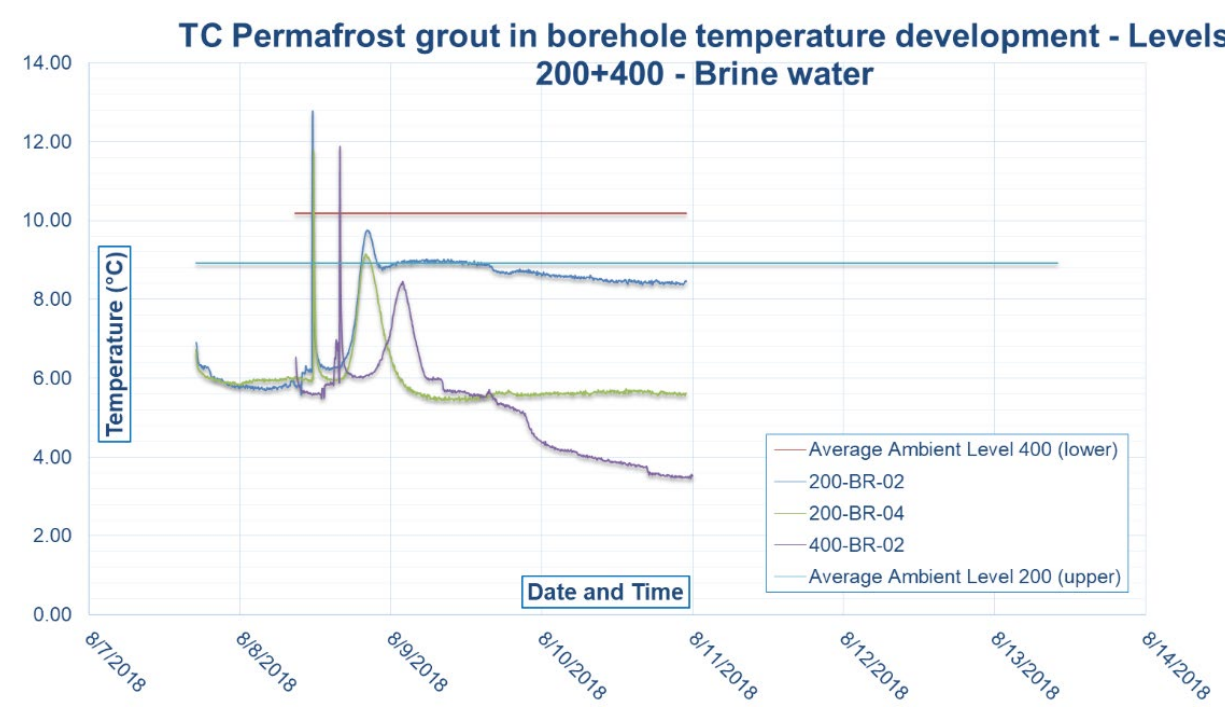

Figure 10 Thick consistency permafrost grout temperature development - level 200 (upper) and level 400 (lower); brine water batches

Table 6 Thick consistency permafrost grout temperature hydration peaks

\begin{tabular}{|c|c|c|c|}
\hline \multicolumn{4}{|c|}{ Level 200 (upper) } \\
\hline 200-FR-04 & $\begin{array}{l}9.07^{\circ} \mathrm{C} @ 8 / 8 / 2018 \text { 1:17:53 PM } \\
\text { (grouted@8/8/2018 10:27:00 AM) }\end{array}$ & 200-BR-02 & $\begin{array}{l}\text { 9.75ㄷ@8/8/2018 9:17:53 PM } \\
\text { (grouted@8/8/2018 11:37:00 AM) }\end{array}$ \\
\hline 200-FR-02 & $\begin{array}{l}\text { 8.46º@8/8/2018 1:07:53 PM } \\
\text { (grouted@8/8/2018 10:32:00 AM) }\end{array}$ & 200-BR-04 & $\begin{array}{l}9.14^{\circ} \mathrm{C} @ 8 / 8 / 2018 \text { 9:02:53 PM } \\
\text { (grouted at 8/8/2018 11:47:00 AM) }\end{array}$ \\
\hline \multicolumn{4}{|c|}{ Level 400 (lower) } \\
\hline 400-FR-04 & $\begin{array}{l}\text { 9.38C@8/8/2018 4:43:00 PM } \\
\text { (grouted@8/8/2018 2:58:00 PM) }\end{array}$ & 400-BR-02 & $\begin{array}{l}\text { 8.46C@8/9/2018 2:53:59 AM } \\
\text { (grouted@8/8/2018 3:53:00 PM) }\end{array}$ \\
\hline 400-FR-02 & $\begin{array}{l}\text { 10.52ㅇ@8/8/2018 4:48:00 PM } \\
\text { (grouted@8/8/2018 3:03:00 PM) }\end{array}$ & $\mathrm{N} / \mathrm{A}$ & N/A \\
\hline
\end{tabular}

FR - Freshwater batch; BR - Brine water batch. 
When the TC permafrost grout is batched with brine water, it appears to delay the hydration peak. On level 200 , the TC permafrost grout batched with freshwater peaks after approximately 2.5 hours (200-FR-04 grouted at 10:27 AM and peaks at 1:17 PM) whereas the TC permafrost grout is batched with brine water peaks after 9.5 hours (200-BR-02 grouted at 11:37 AM and peaks at 9:17 PM). The same tendency is noted on level 400 (lower): the TC permafrost grout batched with freshwater peaks after approximately 1.75 hours (400-FR-04 grouted at 2:58 PM and peaks at 4:43 PM) whereas the TC permafrost grout is batched with brine water peaks after 11.0 hours (grouted at 3:53 $\mathrm{AM}$ and peaks at 2:53 AM).

\section{Conclusion}

The utilisation of modified of a cementitious grout in the harsh cold conditions of the Canadian Arctic has been demonstrated for multiple applications such has surface piles and underground cable bolting. It has also been proven that these new modified cementitious grout mix designs can be adapted to the latest technology in automatic bolters for underground cable bolting. This will improve the mining cycle time in a safe and economical manner, which will allow operations in northern mines to more quickly access ore reserves. By demonstrating that this technology is efficient in this part of the world means that it could potentially be used in other cold region for similar purposes.

\section{Acknowledgement}

The authors would like to express their deepest gratitude to all members who participated in the research program especially the ground control employees of Agnico-Eagle Mines Limited (Meliadine and Amaruq mine site) for the support in installing the testing equipment, collecting and transmitting the test results.

\section{References}

ASTM International 2018, Standard Test Method for Compressive Strength of Cylindrical Concrete Specimens (ASTM C39/C39M), ASTM International, West Conshohocken.

Dufour, JF \& Beaupré, D 1999, 'Development of Shotcrete Mixes to Perform in Permafrost', Proceedings of the Third International Symposium on Sprayed Concrete: Modern Use of Wet Sprayed Concrete for Underground Support, Norway, pp. 196-207.

Hutchinson, DJ \& Diederichs, MS 1996, Cablebolting in Underground Mines, Bitech, Vancouver.

Marek, A, Thorley, S, Dawson, L \& Pickering, R 2012, 'Mechanized bolting-on-board drilling automation and a change in the support regim in low-profile mechanized mining', Proceedings of the Fifth International Platinum Conference - A Catalyst for Change, The Southern African Institute of Mining and Metallurgy, pp. 49-64. 